\title{
FORUM
}

\section{Historical biogeography of the Fanniidae (Insecta, Diptera): A commentary on the age of the family}

\author{
Biogeografía histórica de Fanniidae (Insecta, Diptera): Un comentario sobre la edad \\ de la familia
}

\begin{abstract}
PETER LÖWENBERG-NETO ${ }^{1, ~ *}$, KIRSTERN L.F. HASEYAMA² \& CLAUDIO J.B. DE CARVALHO²
${ }^{1}$ Universidade Federal da Integração Latino-Americana (UNILA), Caixa Postal 2064, 85867-970, Foz do Iguaçu, Paraná, Brasil ${ }^{2}$ Laboratório de Biodiversidade e Biogeografia de Diptera, Universidade Federal do Paraná (UFPR), CP 19020, 81531-980, Curitiba, Paraná, Brasil

${ }^{*}$ Corresponding author: peter.lowenberg@unila.edu.br
\end{abstract}

\begin{abstract}
In a study on Fanniidae biogeography, Dominguez \& Roig-Juñent (2011) argued that the family had a Pangeic origin, Late Jurassic/early Cretaceous ( 146 Ma). However, recent literature on Diptera supports that Schizophora radiation occurred during Cenozoic. Fanniidae is a widespread taxon and it was interpreted under the maximum vicariance paradigm; the consequence was an analysis with no alternative hypothesis, but Pangeic origin. We verified that Fanniidae historical narrative was incongruent with the Gondwana sequential break-up. A second analysis, assuming the Fanniidae origin during early Paleocene $(65 \mathrm{Ma})$, showed congruence with recent geological events and with the Muscidae diversification, a closely related Muscoidea family. Our hypothesis suggests that the Fanniidae originated in Paleogene and they were affected by few events of vicariance and several expansions during Cenozoic.
\end{abstract}

Key words: BPA, DIVA, molecular clock, TreeFitter.

\section{RESUMEN}

En un estudio sobre biogeografía de Fanniidae, Domínguez \& Roig-Juñent (2011) argumentaron que la familia era de origen Pangeico, Jurásico superior/Cretáceo inferior ( 146 Ma). Sin embargo, literatura reciente sobre Diptera, confirma que la radiación de Schizophora ocurrió durante el Cenozoico. Fanniidae es un taxón ampliamente distribuido y fue interpretado bajo el paradigma de máxima vicarianza; la consecuencia, fue un análisis sin hipótesis alternativas, pero de origen pangeico. Nosotros verificamos que la narrativa histórica de Fanniidae es incongruente con la quiebra secuencial de Gondwana. Un segundo análisis, asumiendo el origen de Fanniidae durante el Paleoceno inferior (65 Ma), mostró congruencia con eventos geológicos recientes y con la diversificación de Muscidae, una familia de Muscoidea próximamente relacionada. Nuestra hipótesis sugiere que Fanniidae se originó en el Paleógeno y fueron afectados por pocos eventos de vicarianza y muchas expansiones durante el Cenozoico.

Palabras clave: BPA, DIVA, reloj molecular, TreeFitter.

In a recent paper, Domínguez \& Roig-Juñent (2011) studied the biogeography of the Fanniidae, a worldwide dipteran (Muscoidea) family. The authors' goal was to rescue the historical narrative of the Fanniidae in order to clarify what processes, how and when they shaped the geographic distribution pattern of the family we found today. The authors performed the Dispersal-Vicariance Analysis (Ronquist 1997), an event-based method, with 78 species, including synanthropic species, that occur in eight regions of the globe (North America, Western Palearctic, Eastern
Palearctic, Africa, Australia, New Zealand, Patagonia and Neotropical). The authors interpreted that Fanniidae had a Pangeic origin, Late Jurassic/early Cretaceous ( 146 Ma), assuming that vicariance explained the family spatial pattern and inferring that the geological splitting into Laurasia and Gondwana originated the main clades of the Fanniidae.

Recent literature on Diptera, however, has shown that Schizophora radiation occurred during Cenozoic as well as Muscidae diversification, a closely related Muscoidea family. We argue that Fanniidae origin 
was more recent than Late Jurassic/early Cretaceous as stated by the authors.

A common practice in biogeographic analysis is to infer the age of a taxon based on the age of the geological event that explain the taxon pattern. Vicariance and dispersal, however, can generate similar patterns, and the difference relies on the interpretation of taxa and barrier relative ages. Vicariance assumes that taxa ancestor is older than the barrier formation and the age of descendant origin is similar to the age of the geological event, and dispersal assumes that descendants are younger than barrier formation. Regardless of the taxon, when a given geological event is assumed to explain a diversification event (vicariance), the ancestor is necessarily older than the geological event.

Event-based methods are primarily concerned with the mechanisms that shaped the taxa spatial evolution. For each kind of event is assigned a cost that should be inversely related to the likelihood of event occurrence (Ronquist 2003). In the DIVA context, high costs are attributed to dispersal and extinction, establishing the maximum vicariance scenario (Ronquist 1997). When a widespread taxon is analyzed, the algorithm tends to hypothesize an ancestral area that resembles all modern areas merged. For the Fanniidae, Domínguez \& Roig-Juñent (2011) assumed a Pangeic age of origin while employing DIVA for a worldwide spread taxon. Any inference of taxon age on DIVA results is teleologically biased on the geographic distribution and on the interpretative paradigm (costs).

In order to evaluate the likelihood of events (cost assignment), it is necessary to have a priori hypotheses on taxon age (e.g., Kodandaramaiah 2010). Recent literature based on molecular analysis have supported that the radiation of Schizophora occurred in early Paleogene (65-40 Ma) (see Wiegmann et al. 2011 for a synthesis). Furthermore, a biogeographic study conducted with Muscidae (Muscoidea) in the Neotropics supported that the taxon originated after the Gondwana break-up and diversified in response to climate change occurred during the Cenozoic (Löwenberg-Neto et al. 2011).

Molecular dating is always hypothesis of minimum ages (Heads 2005) and we cannot dismiss an older origin hypothesis.
Notwithstanding, recent studies employing molecular analysis have shown that taxa spread globally and in the southern hemisphere diversified much later than Gondwanan fragmentation. Examples include Eudicots (Renner et al. 2001, Roquet et al. 2008), Cnidaria (Martínez et al. 2010), Anura (Pramuk et al. 2008) and Coleoptera (Sole \& Scholtz 2010).

An appropriated use of DIVA is when the areas have a complex history, with recurrent fusions and break-ups. This is the case of the northern hemisphere (Sanmartín et al. 2001) and not the case of the southern hemisphere. For the southern hemisphere we have a well supported vicariant pattern, which is simpler and hierarchical. Fannia results show that the genus originated in Nearctic and New Zealand or Western Palearctic and New Zealand, and then dispersed to the Holarctic and Holotropical regions (Domínguez \& Roig-Juñent 2011). In this context, DIVA loses power of resolution in comparison with TreeFitter (Sanmartín 2007).

We used TreeFitter to verify if Fanniidae phylogeny and its geographic distribution resemble the sequential break-up of the supercontinent Gondwana during the last 165 millions of years (Sanmartín \& Ronquist 2004). If so, it would support the existence of the Fanniidae during Late Jurassic/early Cretaceous ( $145 \mathrm{Ma})$. Areas of the northern hemisphere were merged into a single one and named "Holarctic", and the general relationship assumed as (Holarctic, ((Northern South America, Africa), (New Zealand, (Southern South America, Australia)))). TreeFitter was executed under default costs (vicariance $=0$, duplication $=0$, extinction $=1$, dispersal $=2$ ). Result showed that the Fanniidae historical narrative was not congruent with the sequential break-up of the Gondwana. Because we assumed a maximum vicariance scenario, we concluded that Fanniidae did not exist during Late Jurassic/early Cretaceous or earlier.

We perform a second analysis employing Brooks Parsimony Analysis (Brooks et al. 2001). BPA can indicate if the data support a general pattern of area relationships and the indication of the processes (vicariance, dispersal or extinction) is later assessed. To interpret BPA results, we assumed that Fanniidae origin was during early Paleogene (65 Ma). Under this scenario the main 
geological event that could promote vicariance was the separation of Patagonia from Australia + New Guinea. All the remaining regions were already established at that time (Sanmartín \& Ronquist 2004). A single area cladogram was obtained: (Africa, ((North America, (Western Palearctic, Eastern Palearctic)), (New Zealand, (Australia, (Patagonia, Neotropical))))). From this result we can infer that vicariance explains the close relationship between Australia and Patagonia + Neotropical, which occurred between 52 and $35 \mathrm{Ma}$.

The relation Patagonia + Neotropical can be explained by expansion and evolution under a climate change scenario. Expansion of tropical lineages into temperate areas shaped the spatial evolution of Muscidae in the Neotropics during Cenozoic (Löwenberg-Neto et al. 2011), which resembles the pattern of several taxa in the Neotropics. The vicariance hypothesis was refuted by the age of the last common ancestor area of Patagonia + Neotropical that dates back $135 \mathrm{Ma}$. Fanniidae occurrence at remaining regions can be attributed to range expansion.

There is a fundamental difference between the results of DIVA and BPA. DIVA reconstructs the ancestral areas for the hypothetical ancestors and maximizes the vicariance and duplication events associated them, while BPA recovers relationships within areas. DIVA does not take into account divergence times in the analysis, so it can easily mislead our interpretation. As BPA does not assume a priori hypothesis on processes, it performed better than DIVA in the Fanniidae dataset, and allowed us to interpret the area cladogram in the light of external evidences.

We believe that the Fanniidae are younger than Late Jurassic/early Cretaceous based on the age of origin and radiation estimated by molecular clock for Schizophora and Muscoidea, and based on the biogeographic pattern of a close related family, Muscidae. Also, we have showed, employing a different method, that the historical narrative of the Fanniidae was not spatially congruent with the sequential break-up of the Gondwana. Our alternative hypothesis suggests that the Fanniidae originated in early Paleogene and it was affected by few events of vicariance and several expansions during Cenozoic.
ACKNOWLEDGEMENTS: KLFH and CJBC are grateful to the Conselho Nacional de Desenvolvimento Científico e Tecnológico (CNPq-Brasil) for graduate scholarship (process number 157808/2010-6) and fellowship (process number 304713/2011-2). We thank Diana Lucía Grisales for translating of the Resumen and James J. Roper Ph.D., for his review of the English.

\section{LITERATURE CITED}

BROOKS D, MGP VAN-VELLER \& DA MCLENNAN (2001) How to do BPA, really. Journal of Biogeography 28: 345-358.

DOMÍNGUEZ MC \& SA ROIG-JUÑENT (2011) Historical biogeographic analysis of the family Fanniidae, with special reference to the austral species of the genus Fannia (Diptera: Fanniidae) using dispersal-vicariance analysis. Revista Chilena de Historia Natural 84: 65-82.

HEADS M (2005) Dating nodes on molecular phylogenies: a critique of molecular biogeography. Cladistics 21: 62-78.

KODANDARAMAIAH U (2010) Use of dispersalvicariance analysis in biogeography - a critique. Journal of Biogeography 37: 3-11.

LÖWENBERG-NETO P, CJB DE CARVALHO \& BA HAWKINS (2011) Tropical niche conservatism as a historical narrative hypothesis for the Neotropics: a case study using the fly family Muscidae. Journal of Biogeography 38: 1936-1947.

MARTÍNEZ DE, AR IÑIGUEZ, KM PERCELL, JB WILLNER, J SIGNOROVITCH \& RD CAMPBELL (2010) Phylogeny and biogeography of Hydra (Cnidaria: Hydridae) using mithocondrial and nuclear DNA sequences. Molecular Phylogenetics and Evolution 57: 403-410.

PRAMUK JB, T ROBERTSON, JW SITES JR \& BP NOONAN (2008) Around the world in 10 million years: Biogeography of the nearly cosmopolitan true toads (Anura: Bufonidae). Global Ecology and Biogeography 17: 72-83.

RENNER SS, G CLAUSING \& K MEYER (2001) Historical biogeography of Melastomataceae: The roles of Tertiary migration and long-distance dispersal. American Journal of Botany 88: 12901300 .

RONQUIST F (1997) Dispersal-vicariance analysis: A new approach to the quantification of historical biogeography. Systematic Biology 46: 195-203.

RONQUIST F (2003) Parsimony analysis of coevolving species associations. In: Page RDM (ed) Cospeciation: 22-64. Chicago University Press, Chicago.

ROQUET C, I SANMARTÍN, N GARCIA-JACAS, L SÁEZ, A SUSANNA, N WIKSTRÖM \& JJ ALDASORO (2009) Reconstruction the history of Campanulaceae with Bayesian approach to molecular dating and dispersal-vicariance analysis. Molecular Phylogenetics and Evolution 52: 575-587.

SOLE CL \& CH SCHOLTZ (2010) Did dung beetles arise in Africa? A phylogenetic hypothesis based on five gene regions. Molecular Phylogenetics and Evolution 56: 631-641.

SANMARTÍN I \& F RONQUIST (2004) Southern hemisphere biogeography inferred by event-based models: Plant versus animal patterns. Systematic Biology 53: 216-243. 
SANMARTIN I (2007) Event-based biogeography: Integrating patterns, processes, and time. In: Ebach MC \& RS Tangney (eds) Biogeography in a changing world: 135-159. The systematics association special volume series 70, CRC Press, London.

SANMARTÍN I, IH ENGHOFF \& F RONQUIST (2001) Patterns of animal dispersal, vicariance and diversification in Holarctic. Biological Journal of the Linnean Society 73: 216-243.

\section{Editorial responsibility: Elie Poulin}

Received November 24, 2011; accepted August 14, 2012
WIEGMANN BM, MD TRAUTWEIN, IS WINKLER, NB BARR, JW KIM et al. (2011) Episodic radiations in the fly tree of life. Proceedings of the National Academy of Sciences USA 108: 5690-5695. 